\title{
Interethnic dating preferences of Roma and non-Roma secondary school students
}

Integrated schooling is known to induce interethnic friendship relations, however it also creates the opportunity of interethnic dating. Interethnic personal relationships or long-term exposure decreases ethnic prejudice, thus it is proposed that willingness to date between ethnic groups may also increase. The question arises, whether in the school context exposure is enough for this mechanism to emerge, or personal contact is necessary. It must also be taken into account, that romantic relationships are embedded in status relations within schools. Based on a 'social exchange' mechanism, it is assumed that the less popular members of the majority groups are those, who are more willing to form interethnic dating relations. To address the above questions empirically, the data of 1213 Hungarian 9th grade students in 43 classes was analysed. Preferences of Roma and non-Roma students were measured by dyadic attribution of physical attractiveness and nominations of willingness to date. Results of multilevel p2 models suggest that mixed groups are not sufficient, but personal contacts are necessary to decrease same ethnicity preferences in dating. An additional tendency is salient: among majority students, those who are isolated from the friendship networks are the ones who are more willing to date members of the minority group.

Keywords: romantic relationships; dating; intergroup contact; adolescents; Roma minority

\section{Introduction}

Social problems of the Roma population on the Eastern side of Europe correspond to the social problems concerning the Black and Hispanic population in the U.S. and the immigrant population in Western European countries. The Roma people are one of Europe's largest ethnic minorities, whose disadvantages can be observed in several fields. For example, only $15 \%$ of young Roma adults complete upper secondary or general vocational education, less than third of the adult population is in paid 
employment, and one third of the population reports unemployed status. About $45 \%$ of the population lives in poor housing conditions (FRA 2012).

In Hungary, the Roma are estimated to comprise 5 to 6 percent of the total population and 10 to 12 percent of the young adolescent population (Kemény and Janky 2006). Concerning education, the gap between Roma and non-Roma students in standardized test scores is substantial, about one standard deviation of the national average. It can be in large part explained by differences in income, wealth, and parental education, however school segregation also adds to this difference (Kertesi and Kézdi 2011, 2014). The inequality is also present in secondary school enrolment. Half of Roma go to vocational schools, which do not provide maturity certificate, a prerequisite for higher education, in contrast to only $19 \%$ of the non-Roma cohorts. On the other hand, only $9 \%$ of Roma students go to grammar schools, compared to $38 \%$ of their nonRoma fellows. (The third choice is secondary vocational school, which provide maturity exam and also vocational training) (Kertesi and Kézdi 2010).

In light of the surveys of attitudes, stereotypes and prejudices, the Roma are the most rejected of all minority groups (Csepeli, Örkény, and Székelyi 2000), and what is more important, these attitudes can already be observed in secondary school (Szabó and Örkény 1998; Ligeti 2003; Murányi 2006; Váradi 2014). It was also shown that contact with the Roma minority reduces the level of this prejudice (Ligeti 2003; Váradi 2014).

There is substantial attention dedicated to the policy consequences of these problems, and different anti-segregational policy measures were recommended (Havas 2008). However, unobtrusive segregationist policies of primary schools can be still observed (Kertesi and Kézdi 2013).

Consequences of ethnically integrated schooling can be analysed by examining its effects on school performance and racial attitudes. Interracial friendship relations are 
important subject for this analysis, as peer acceptance contributes to educational motivation and success, decreases the probability of dropping out (Lubbers 2003), and close interracial friendships influence racial attitudes (Powers and Ellison 1995). Therefore, an important aspect of school integration is that it increases interethnic contact opportunities, which may contribute to decreasing ethnic homophily (the tendency of people to interact with others of similar ethnicity). However, the more interesting and policy relevant question is, whether students change their behaviour when such a more heterogeneous setting is given. If people interact most often with others with the same ethnicity, that signals racial division not integration (Moody 2001).

The examined interactions in this study will be preferences for forming interethnic dating relationships. Inter-ethnic romantic relationships, among others, are interesting for analysis, as they are generally considered as a litmus test for successful integration (Song 2009; Kalmijn 1998). Furthermore, on the one hand, developing romantic relationships were found to be based on mixed-gender friendships (Connolly, Furman, and Konarski 2000; Connolly et al. 2004), but it was also shown that they function as bridges among subgroups of friends in adolescent networks (Kreager and Haynie 2011).

In Hungary, partner preferences of Roma and non-Roma population have been studied as a measure of xenophobia and social distance: in a national representative sample respondents were asked if they would object if a close family member married someone with Roma origin (Csepeli, Fábián, and Sík 1998). The figure that 58\% of respondents would oppose or strongly oppose such a match indicates the presence of a non-tolerant norm. Less is known about the preferences of the Roma towards interethnic relationships. Quantitative data is only available about intermarriage showing a very high $84 \%$ in-marriage rate of the Roma population, which is significantly higher 
than this ratio for other minorities in Hungary (Tóth and Vékás 2008). Anthropological studies of villages suggest that while for the Hungarian community a mixed marriage is a norm violation, which is sanctioned, for the Roma such a marriage can be framed as social ascent, however, it creates similar tensions within the family and the community (Kovai 2015; Bakó 2009).

Thus, the basic question of the present study is whether more contact to Roma students at school changes the dating preferences of majority students. However, even in integrated schools, physical proximity may not be enough for interethnic relations to improve. Therefore, the second question arises, whether in the school context pure exposure is enough for such mechanism to emerge, or other signs of integration, such as personal contacts (friendships) are necessary. Beyond the question that how many majority students would form inter-ethnic dating relationships, it is also interesting that which members of the majority would be willing to form these. Specifically, the role of in-group status will be analysed.

To address the above questions, a sample of 1213 secondary school students from seven Hungarian schools were asked, whom they find attractive, and whom they would date in the class. Ethnic composition of the classes and actual friendship measures of students will be used as key independent variables. These observations are structured in dyads, where the preference may be influenced by the individual characteristics of the pair of students, and reciprocity may also be present. The observations have a multilevel structure, the dyads are observed in relation to (pairs of) individuals, which are themselves observed in classes. These effects can be taken into account with using multilevel p2 models.

\section{Theory and hypotheses}

In partner selection homophily and homogamy can be observed widely in societies. 
Theories of partner selection trace back this phenomenon to three factors: preferences of the individuals, choice opportunities, and third party influences (Kalmijn 1998). Concerning ethnicity, this means that the trend of people selecting same-ethnicity partners may be the consequence of the fact that people prefer same race partners for dating, their social environment discourages them crossing ethnic boundaries, and because people usually meet same race others in societal settings.

In fact, a strong same race preference can be found in partner choice. Studies from the field of psychology revealed this phenomenon using direct questions (Sprecher, Sullivan, and Hatfield 1994), and in recent years, the general diffusion of new dating services created additional opportunities for economists to deduce preference patterns from the behaviour of individuals (so called revealed preferences method). Hitsch, Hortaçsu, and Ariely (2010) analysed the log file of an online dating service, and compared the profiles that were actually connected to those that were viewed by the users. They found a negative effect of dissimilarity in race for Blacks, Whites, Asians and Latinos. Similar results were obtained using speed dating experiments (Fisman et al. 2008). Preferences for interethnic dating may vary in different groups of societies. For example, conservative political views and religion decreases one's willingness to date other races (Eastwick et al. 2009; Yancey 2007).

Considering third parties, it was shown that one reason for interethnic and interracial dating to be rare is that it still a stigma (Kaba 2011). Studies form the US revealed that white members of interracial couples experience 'rebound racism' (Frankenberg 1993), and disapproval from their family and friends (Miller, Olson, and Fazio 2004). These tensions can already be found in high schools. Vaquera and Kao (2005) reported that interracial couples are less likely to display publicly their 
affections, and Kreager (2008) found that getting involved in interracial dating increases perceived peer trouble at school.

In addition to preferences, composition of the available marriage markets influences partner selection (Lichter et al. 1992). The founders of this research tradition, Blau and Schwartz (1984) have shown that the relative size of different groups in U.S. metropolitan areas influence partner selection, and heterogeneity decreases homogamy. On the other hand, if availability of preferred partners is decreased in a context people tend to turn elsewhere for potential candidates. For example, in schools where samerace partners are scarce, students of these ethnicities tend to select partners outside of the schools (Strully 2013).

Using a different formulation, one can say that the size and number of ethnic groups themselves generate a certain level of homophily. However, the more interesting question is, whether the choice of individuals is also altered compared to pure random selection, in addition to this effect. These are called baseline and inbreeding (or choice) homophily (McPherson, Smith-Lovin, and Cook 2001), which may indicate the influence of third parties or the change of preferences.

The reason for assuming such impact of group composition on preferences is provided by the research tradition of contact theory. This originates from Allport (1954), who examined the conditions under which social contacts between individuals decrease prejudice. According to this, under specific conditions (equal status of the groups, existence of common goals, intergroup cooperation and support of the authorities) based on the characteristics and experience of individuals, initial contact between groups takes place which leads to liking on the individual level; over time established personal relationships result in decreased prejudice (Pettigrew 1998). A meta-analysis of the rich research tradition using 515 empirical studies supports the 
relationship between personal interaction and decreasing prejudice. Moreover, this relationship seems to hold even without Allport's original necessary conditions (Pettigrew and Tropp 2006).

On the other hand, there is evidence about an opposite effect between minority group size and attitudes. The core proposition of ethnic competition theory is that an increased level of competition on the individual and contextual levels reinforces ethnic exclusionism (Scheepers, Gijsberts, and Coenders 2002). Applied to the question of anti-immigration attitudes, it was shown that an increase in non-European immigration is associated with more exclusionist attitudes among the population with lower levels of formal education or those working in low status jobs (Scheepers, Gijsberts, and Coenders 2002; Semyonov, Raijman, and Gorodzeisky 2006)

About these potentially conflicting effects Vermeij, van Duijn, and Baerveldt (2009) note, that contact theory does not refer to casual and superficial contact according to Allport, this would rather augment hostility, thus for those types of relationships predictions of ethnic competition theory apply. In fact, ethnic competition theory typically examines casual and superficial contacts in large scale settings. Therefore, it can be assumed that in a small scale setting with frequent contact - such as school classes - the positive effect of contact with minorities may balance or even dominate the negative one.

A possible consequence of contact theory regarding interethnic dating relationships is that increased intergroup contact subsequently results in more positive attitudes, which may also manifest in dating preferences. About increased contact, Pettigrew and Tropp (2006) emphasize that physical proximity of the two ethnic groups is not enough, established contact should be assumed. This may be assumed in long- 
term situations where contact is unavoidable such as in small classrooms, or it can be observed directly.

Assuming unavoidable contacts in the classrooms, it can be proposed that with an increasing share of minority students, the inclination of majority students to date such pupils increases (H.1.).

However, as Schofield and Eurich-Fulcer (2001) notes, based on the studies of Klein and Eshel (1980) and Gerard, Jackson, and Conolley (1975), sitting in the same classroom may still not be enough for intergroup relations to improve. Anxiety may cause avoidance of contact with other ethnicities, so a resegregation of students in free times may occur. Therefore, the interaction systems in the school, for example the organisation of extracurricular activities are crucial (Patchen 1982; Moody 2001).

An observed evidence for interethnic contact may be the presence of interethnic friendship relations. Empirical results support this link between friendships and dating: having interethnic friendships influenced positively the likelihood of interethnic dating in the sample of Asian American college students (Mok 1999). Qualitative results from an elite college study also suggested, that segregation of friendship networks contributes to maintaining racial homophily in dating (McClintock 2010). Beyond the contact hypothesis, Clark-Ibáñez and Felmlee describe three mechanisms in relation to the effect of family and friendship networks on interethnic dating: (1) networks act as the source of information, thus reduce uncertainty, (2) support from these networks influences the viability of the relationship, and (3) networks set norms and sanction non-normative behaviour (this corresponds to Kalmijn's 'third party influence' factor). Using the survey data of college students, they have found that friends' ethnic diversity influences positively the chance of interethnic dating. On the other hand, the ethnic diversity of the respondents' neighbourhoods and high schools did not have such 
independent effect. Keels and Harris (2014) have also shown that more heterogeneous friendship networks increase the likelihood of interethnic dating in their study using survey data from 24 predominantly white colleges. Moreover, in contrast to the above results, their study showed that a lower share of the same ethnicity students in the college had an additional positive effect on interethnic dating in their study. According to these, it is assumed that preferences for same ethnicity in dating are weaker among those majority students who had friendships with minority students (H.2.).

An interesting question is, whether this is additional to the effect of groups' ethnic composition when both effects are entered into the model, as found by Keels and Harris (2014), or group heterogeneity does not matter beyond an existing effect of friendship diversity, as in the case of Clark-Ibáñez and Felmlee (2004). As classes are relatively small groups in contrast to the colleges and schools analysed by these studies, and in the Hungarian secondary schools organization of activities are largely based on class membership, an additional effect of class heterogeneity beyond friendship diversity may be assumed (H.3.).

In addition to the general tendencies in attitudes towards dating with minorities, it is also interesting to analyse which students will form interethnic relations. To study this, interdependence of status and romantic relationships must be taken into account. Friendship relations were found important in the development of dating relations. Size of same sex friendship network was related to the size of opposite sex friendship network, which had a positive effect on developing dating relations in the subsequent years in early adolescence (Connolly, Furman, and Konarski 2000; Connolly et al. 2004). Popularity itself was found to be an important predictor of developing dating relationships (McCarthy and Casey 2008), and it also influenced partner selection (Simon, Aikins, amd Prinstein 2008) On the other hand, experience with the opposite 
gender directly influences popularity within the peer groups (Kreager and Staff 2009). Thus, the status position of a student constrains the possible pool of partners, and when choosing a partner, status consequences of the choice also need to be taken into account. Such status considerations of partner selection are analysed in the social exchange framework. This approach is based on a utility maximization assumption, that each individual is assumed to carry an approximate 'market value', depending on the degree to which he or she possesses valued traits such as beauty, intelligence, charm, wealth, and social status. It is assumed that if every individual seeks the best value in a mate, individuals of approximately equal value will tend to pair up (Kenrick et al. 1993, 951). However, it is not necessary that couples with equivalent resources are actually similar in all relevant characteristics, as 'the equivalence could result from a balance of pluses and minuses in different areas' (Schoen and Wooldredge 1989). Empirical studies of the status-caste exchange have shown that choosing partners from minorities (which is assumed to be associated with lower status) is often compensated by their higher educational status (Schoen and Wooldredge 1989; Kalmijn 1993; Fu 2001). Translated to the adolescent society, an ethnicity-popularity exchange may suggest, that the less popular members of the majority groups are the ones who are more willing to form interethnic relations. (H.4.)

\section{Methods}

\section{Sample}

The study is based on data from the 'Wired into Each Other: Network Dynamics of Adolescents in the Light of Status Competition, School Performance, Exclusion and Integration' project of the Hungarian Research Centre for Education and Network Studies. The sample includes seven secondary schools from Hungary: two from the 
capital, two from a major city in Eastern Hungary, and three schools from two nearby smaller towns. As one of the research goals was to examine social inclusion, the selection criterion of these localities was the existence of a notable Roma minority. Additionally, schools were selected to ensure that in each location each training type (grammar school, secondary vocational school and vocational school) is present in the sample (Table 1). Since we used this targeted sampling, the sample cannot be considered as representative of the region or Hungary. The target population includes all students of the selected schools, who were in the 9th grade in the academic year 201011. This study uses wave 1 of the data collection carried out two and half months after the students entered secondary school (9th grade) in 2010. At the time of the data collection the students' median age was 15.2 years.

Altogether 1,356 students were contacted from 44 classes of the seven secondary schools. Students, who were absent on the day of the data collection, and those whose parents objected to their children participating in the survey were excluded. Additionally, one class was excluded from the sample, as it contained only boys. These exclusions resulted in the data of 1,213 students, which was used for analysis.

Ethnic compositions of the schools are largely different by tracking: we can hardly find Roma students in grammar school classes, but only in secondary vocational school and vocational classes. A similar inequality among the tracks can be found considering parental education (Table 1).

[Table 1 near here]

\section{Independent variables}

The main independent variable in the analysis is ethnic origin. Roma origin was measured using self-assessment. $27.4 \%$ of the students answering this question reported 
that they have Roma or partly Roma family background (there were $8.3 \%$ missing values due to nonresponse). The share of Roma students was measured on the class level calculated from the above variable. The ethnic composition of classes was diverse. In eight classes no one identified him or herself as Roma, in seven classes less than $10 \%$ did, but in eight classes the share of the Roma students exceeded 60\% (Figure 1).

[Figure 1 near here]

The interethnic friendship measure is based on a question asking students to indicate the type of relationship they have with each of their classmates, whether it is '-2: I hate her, she is my enemy -1: I don't like her, 0: neutral, 1: I like her, 2: she is my friend'. The answers of ' 2 ' were used to identify friendships. Afterwards, these variables were transformed to capture the relationship of non-Roma students with Roma students: for any non-Roma respondent relationship with Roma was identified if she or he indicated a friendship tie to at least one Roma classmate. $30.9 \%$ of non-Roma respondents reported such friendships.

To measure status within the group, popularity (number of friends) may be a valid measurement. As individual preferences are of our interest, individual perception of popularity is relevant. Therefore, instead of friendship indegree, friendship outdegree was used. In the basic specification, the proxy of low status vs. not low status is isolated position (outdegreee $=0$ ) vs. non-isolated (outdegree $>0$ ). For alternative specification the measurement of the outdegree itself was also used. Students marked on average 6.32 friends in the class (s.d.=4.97), with the median of 5 friends. The share of isolated students was $7.5 \%$.

Additionally, romantic relationships were found to be based on mixed-gender friendships. Although it was not shown for the dyadic level (that friendships evolve to romantic affiliations) only on the individual one (that having mixed gender friendships 
predicts the development of romantic relationships) (Connolly, Furman, and Konarski 2000; Connolly et al. 2004), but if it also exist on the dyadic level, it provides an alternative explanation for the potential correlation between mixed-ethnicity friendships and romantic preferences. Therefore the dyadic indication of friendship was used as a control variable.

\section{Dependent variables}

Two measures of dating preferences were selected for analysis. First, in order to measure willingness to date directly, respondents were asked to mark those, 'Who they would date' from a list of their classmates. This is a dyad level observation which is available for every potential dyad in the class on a 0/1 level. In addition, the measure of attraction was analysed by asking respondents to mark those 'Who they think to be pretty or handsome' from the list of all members of the class, as it is known from previous studies that physical attractiveness is a very strong predictor of dating preferences for males and females (Hitsch, Hortaçsu, and Ariely 2010; Fisman et al. 2008). Frequency distributions of attraction and dating willingness differed notably. Students marked $11.6 \%$ of their opposite gender classmates as attractive, but they were willing to date only $2.8 \%$ of them. A significant preference for same ethnicity can be observed in these. Non-Roma students chose non-Roma classmates and Roma students Roma classmates more frequently for both questions.

[Table 2 near here]

\section{Statistical models}

When observations refer to social networks, one should expect that social mechanisms, such as reciprocity, homophily, and transitivity are present, which in traditional regression models may cause biased estimation (Snijders 2011). Concerning friendship 
networks, it was shown that both the transitivity mechanism (the fact that two friends of mine also tend to be friends) and reciprocity amplifies homophily (Wimmer and Lewis 2010). Concerning dating relationships, the presence of reciprocity is reasonable to assume, but transitivity and other triadic effects are less relevant, as no direct triad can be assumed in a heterosexual dating network. Accordingly, multilevel p2 models (Zijlstra, van Duijn, and Snijders 2006) were chosen for analysis. This model addresses reciprocity directly, therefore eliminating the potential biases from this source. Additionally, it considers the multilevel structure of the data, that we observe dyadic choices, which are cross-nested in individuals, who are nested in groups.

The multilevel p2 model is based on the p2 model (Duijn, Snijders, and Zijlstra 2004) which is specified to measure directed ties in social networks. In this setting a relationship between two actors is measured by the variable $Y_{i j}$ which equals 1 if there is a directed tie from actor $i$ to $j$. The model estimates the four possible outcomes $(0,0 ; 0,1$; $1,0 ; 1,1)$ of the dyadic relationship using a sender, a receiver, a density and a reciprocity parameter. The possibility to add covariates for these effects makes the model suitable for the analysis of the influence of individual and network characteristics on these parameters. The $\mathrm{p} 2$ uses an exponential function to model these probabilities, similarly to logistic regression models, thus the interpretation of the parameters is similar to that of the logistic regressions (Zijlstra, Veenstra, and Van Duijn 2008).

The multilevel p2 extends the original model for the analysis of multiple networks. It assumes identical p2 specifications for each network, which can be different in size. It adds a group level random effect to the original sender, receiver, density and reciprocity parameters as they are observations from different networks, and a group level parameter for density and reciprocity which allows for the analysis of group level covariates. Therefore, it can be regarded as a three level random effects 
model where ties (level 1) are cross-nested in individuals (level 2), who are nested in groups (level 3) (Zijlstra, van Duijn, and Snijders 2006)

The key interest considering the hypotheses is the preferences of non-Roma students towards opposite gender classmates. Therefore, the cross-gender dyads were selected for the analysis, where the respondent is non-Roma. The effect of the partner's ethnicity on the respondents' dating preferences can be inferred by adding the 'Receiver Roma' covariate to the $\mathrm{p} 2$ models. To measure class composition effect, two effects were used. The main effect of the share of the Roma students in the class ('Share of Roma' covariate) estimates the average effect of class composition on liking. Its interaction with the 'Receiver Roma' variable ('Share x receiver Roma') indicates how the share of the Roma students in the class alters the desirability of Roma students, thus it constitutes my key interest regarding H.1.

For analysing the effect of having Roma friends on dating preferences towards Roma (H2-H3), the interaction 'Has Roma friends x receiver Roma' will be entered to the model. Its main effect ('Has Roma friends') should be included simultaneously, to control for the possible impact of having Roma friends on liking anyone, irrespectively of ethnicity. The final hypothesis about the impact of perceived status on willingness to date Roma students will be tested by adding the 'Has any friends x Receiver Roma' interaction. Again, its the main effect ('Has any friends') should be added to the model at the same time.

\section{Results}

To test the hypotheses, effects are added to the p2 models in the following order. First, the ethnicity of the potential partner and the ethnic composition of the class are added to test H1. Second, the interethnic friendship and the friendship status are included corresponding to H2-H4. Finally, the models are completed by adding dyadic level 
friendship controls. The coefficients of the models with dependent variable attraction are presented in Table 3, and Table 4 displays the results with the willingness to date dependent variable in a similar structure.

First, taking into account the model of finding someone attractive (Table 3), it turns out that the main effect of the receiver's ethnicity is statistically significant, indicating that non-Roma students find same ethnicity classmates more attractive compared to Roma ones (Column A). The 'Share x receiver Roma' covariate indicates that the increasing share of Roma students in the class raises the probability that they are perceived as attractive by their non-Roma peers, which corresponds to H.1. The parameter of the share of the Roma in the class is also significant and negative, showing that in classes with more Roma students the probability of attraction between two students irrespectively from ethnicity is decreased. Furthermore, it is visible that no significant reciprocity mechanism is present in the choice of attractive classmates.

Adding the interethnic personal contact (that the respondent has at least one Roma friend) interacted with the Roma ethnicity of the receiver, (Column B), the positive and statistically significant estimate signifies that having friendships with Roma students increases attraction towards Roma classmates, corresponding to H.2.Furthermore, when taking a look to the estimate of 'Has any friends $\mathrm{x}$ receiver Roma' parameter, it appears that non-isolated status in the friendship network decreases the likelihood of being attracted to Roma students (thus isolated status increases it, corresponding to H.4.). On the other hand, with the inclusion of these variables, estimate of the group composition effect becomes smaller and insignificant, suggesting that group heterogeneity does not have an effect on interethnic preferences after friendship relationships are taken into account, which is in contrast to H.3. assuming additional effects. 
Finally, if dyadic level friendship controls are added to the models (friendship nomination and its interaction with Roma ethnicity of the receiver, Column C), the following conclusions can be drawn. Friendship has a positive effect, so if an opposite gender classmate is my friend, I also tend to find her attractive. This is true irrespectively of ethnicity ('Friend x receiver Roma' is insignificant). Finally, crossethnic friendships' positive effect exists beyond this dyadic level, that is majority students having Roma friends also find their non-friend Roma classmates more attractive (compared to those, who do not have Roma friends).

[Table 3 near here]

Turning to the models of willingness to date (Table 4), the density parameter indicates a much sparser network than in the case of finding someone attractive, and we do not find significant reciprocity mechanism again (Column A). The ethnic parameters show similar tendencies to the attractiveness model, however, the receiver Roma parameter, and the effect of the share of the Roma students in the class lose statistical significance (H.1).

With the inclusion of the effect of interethnic friendship and being isolated in the friendship networks (Column B), the results are the same as previously, meaning that interethnic friendship has a significant positive effect on Non-Roma students' willingness to date Roma pupils (H.2), and isolated status also increases this likelihood (H.4). The main effect of these variables are not significant, showing that being isolated, or having Roma friends do not change non-Roma students' willingness to date with their same ethnicity classmates

Adding the dyadic level friendship controls however slightly decreases the effects of cross-ethnic friendships and friendship isolation, which results in the loss off statistical significance of these parameters (Column C). 
However, the tendencies of the 'attraction' and 'willingness to date' models are consistent in points of the H.2-H.4. hypotheses, suggesting that interethnic friendships have a positive effect on interethnic dating preferences (H.2.), they dominate the effect of class composition (in contrast to H.3.), and the preferences seem to reflect strategic considerations of status exchange: being isolated from friendships is associated with decreased same-ethnicity preferences in dating (H.4.). Concerning H.1., the effect of ethnic composition of classes is only significant in the attraction model.

[Table 4 near here]

Regarding the previous specifications some additional questions arise logically. First, it is interesting to examine, whether the effects of class composition (H.1.), inter-ethnic friendships (H.2, H.3.), and isolated status (H.4.) are present in the willingness to date preference if we control for attributed attractiveness. The results of this specification are presented in Table 5 Column A. It is visible that the effects of interest regarding H.1H.4 are not significant in this specification, thus these social effects were already present when considering attractiveness. After the reported attractiveness is taken into account, no such social considerations are discernible. Thus, it is not the case that students may consider someone attractive but judge him or her to have the 'wrong' ethnicity; instead they do not even report them attractive. Over physical attraction only friendship nomination remains a significant predictor of willingness to date.

It is also interesting to see the extent to which the results are dependent on the presented specifications. Interethnic personal relationship was coded as present or not depending on whether the non-Roma student had zero or a positive number of Roma friends. Low status was coded if the respondent reported no friends in the class. However, both variables could have been measured on a continuous scale. One alternative is to use simply the number of friends as a measurement; results in this 
specification are presented in Table 5 Column B and C. They show that only the interethnic friendship effect remain significant, and only in the attraction model.

However, it can be argued that both for status and for interethnic contact, the relevant difference is not whether one has ten or eleven friends, but the substantial difference is on the lower part of this scale. A corresponding measure is presented in Table 5 Column D and E, when interethnic contact and status is measured by the $\log ($ number of friends +1$)$. The results in this case are that both interethnic contact and low status is significant in the attraction model, and the tendencies are similar, but statistically not significant at 5\% level in the attraction model. These results are the same as the findings of the original specification, where inter-ethnic friendships were coded as present or missing, and in-class status as having or not having friends. This suggests that the creation of the first few inter-ethnic friendship connections and the making of the first few friends matter for inter-ethnic dating preferences.

[Table 5 near here]

Considering the results one may doubt their attribution to the presented contact mechanism. Is it not possible that the relationships originated from earlier than the observed period? To test this, additional information from the questionnaire was used. A network question asked the respondents about each of their classmates, whether they knew them well before the class was created. From this question - similarly to the variables of interethnic friendships - a variable was created indicating whether the respondent knew any of his/her Roma classmates well, before the class was created. Inclusion of this variable in the models (results not shown here) indicated that knowing Roma classmates before secondary school did not influence attraction and willingness to date between non-Roma and Roma classmates, but having Roma friends two months after the class was created had a positive effect on them. This observation corresponds 
to the original hypothesis that what we see in the models is the result of interethnic contact. However, it does not eliminate all alternative explanations. The observed relationship is identified from cross-sectional observations, therefore other nonobserved heterogeneity effects may be present - for example the effect of the ethnic composition of the towns / neighbourhoods where the students come from which may influence attitudes towards minorities.

\section{Discussion}

The first aim of the present study was to analyse the interaction between the ethnic composition of classes and ethnic preferences in dating. Using multilevel p2 models on the sample of 9th grade Roma and non-Roma students in Hungary the following interaction was found: in classes with a higher share of Roma students, non-Roma respondents found Roma classmates more attractive. On the other hand, this effect was not significant for the question asking about whom the respondent would date.

The second goal was to test the effect of cross-ethnic friendship relationships. It was shown in previous studies that ethnic diversity of friendships influences interethnic dating (Clark-Ibáñez and Felmlee 2004; Keels and Harris 2014), and I argued that a possible source of this effect can be that they create less restrictive preferences towards inter-ethnic dating. Results supported the hypothesis that having Roma friends increases the probability that non-Roma respondents find their Roma classmates attractive, and also that they are willing to date Roma classmates.

Of these two effects, the latter was found to be the key mechanism: inclusion of interethnic friendships in the models ruled out group composition effects. This suggests that, as far as we can generalize from the sample of Hungarian secondary school students, ethnically heterogeneous groups are not sufficient, actual personal relationships are the ones that influence interethnic (dating) preferences. 
These results correspond to Lubbers (2003), finding no effect of ethnic class composition on interethnic friendships, and Clark-Ibanez and Felmlee (2004), who found no effect of ethnic composition of schools on interethnic dating relationships. However, it should be noted that these studies don't fully match to the presented research, as the key interest here was dating preferences. Studies on integrated education also suggest that having ethnically mixed schools may not be sufficient for inter-ethnic interactions to develop, as re-segregation of students, the lack of integrated extracurricular activities, and social anxiety may prevent their development (Schofield and Eurich-Fulcer 2001).

It must be added, that although the above mechanisms were presented as basically different, in practice they can be imagined as a continuum. The ethnic structure of groups may influence dating intentions, as in the classes the two ethnicities have the opportunity to interact, and different types of interactions do occur. Ethnic integration itself cannot have such an effect if no interaction is assumed, and what was found empirically is that the share of minority students did not have a significant additional effect after cross-ethnic friendships were taken into account.

The final aim of the study was to test the presence of a status - ethnicity social exchange mechanism, or more precisely, the strategic adjustment of the preferences according to this exchange. Being isolated in the friendship network signifies low status within the class. As status is an important asset for successful dating (McCarthy and Casey 2008), students may form their preferences accordingly to avoid disappointments. Thus, relatively low status members of the majority (high status) group will be more willing to choose partners from the minority (low status) groups. This hypothesis was supported by the data. 
Our results were presented as ethnic effects. However, these classmates probably differ in many other characteristics as well, for example in socio-economic status or popularity within the class, which may also influence the desirability of the potential partners. Not including these variables in the models was intentional. The reason behind not including socio-economic status was that classification of the Roma is highly dependent on socio-economic status (Ladányi and Szelényi 2006); therefore in this case it would be misleading to calculate the net effects of Roma ethnicity independently from status. In case of the status among the peers, one might assume that social exclusion of the Roma influence these network positions as well. Therefore, controlling for these would mean that we are trying to measure the net exclusion in dating controlled for other types of exclusions that are present, which was not the purpose of this research. In this respect, the present measurement is similar to ones used in revealed preference studies (Hitsch, Hortaçsu, and Ariely 2010; Fisman et al. 2008), where one can infer preferences from choices, however, not all attributes of the actors (which are possibly correlated to race or ethnicity) are known, therefore the race or ethnicity coefficient actually includes their effects too.

The findings about the importance of inter-ethnic friendships underline that the formation of these friendships between the Roma and non-Roma students are important field for further research. About this, Boda and Néray (2015) emphasize the importance of negative relations (majority students did not have fewer friends among Roma than among themselves, but disliking was more probable towards the Roma); and Hajdu, Kertesi, and Kézdi (2015) highlights that school achievement is a positive factor for the acceptance of Roma students as friends. Based on the current result, the status within the majority community may also be an important factor. Considering dating relationships, the current study did not uncover the effect of gender, however, one may 
expect such differences (Kreager and Staff 2009; Keels and Harris 2014), therefore it may also be a direction for further research.

After taking into consideration the methodological limitations, it can be concluded that if the identified effects at least partly remain stable and the preferences manifest in actual interethnic dating relationships, then the results may have implications for studying the effects of integrated education. The role of interethnic romantic relationships may result in decreased prejudice towards minorities, in better educational performance (Giordano et al. 2008), and in social mobility through marriage. Obviously, when getting engaged to such speculations, it must be stressed that the current study is only about the preferences, not about actual behaviour. To translate them to actual choices, additional research would be necessary; for example the analysis of whether inter-ethnic attractions are less likely to manifest in actual dating than same ethnicity ones. Unfortunately, not much is known about this from the literature, and the low incidence of actual dating relationships in the current sample prevents such analysis. The related studies about the transition likelihood of interracial dating and cohabitation relationships to marriages found no difference between interracial and homogeneous couples (Blackwell and Lichter 2004), or found an existing difference, which however decreased over the previous decades (Joyner and Kao 2005).

The basic conclusion of the present study is that when only looking at ethnic diversity of classes, higher share of Roma students in the class was associated with more favourable dating preferences towards them. However, when examining it together with the effect of inter-ethnic friendships, the effect of these friendships were found to be positive, and class composition did not have an additional effect. These results underline, that superficial integration may not be enough, creating the conditions and opportunities for friendship relations to develop is important for actual impacts. 


\section{References}

Allport, Gordon, W. 1954. The Nature of Prejudice. Reading, MA: Addison-Wesley.

Bakó, Boglárka. 2009. "Romlott nők és tiszta lányok - Egy dél-erdélyi roma közösség női normái.” Rubicon 2009(4).

http://www.rubicon.hu/magyar/oldalak/romlott_nok_es_tiszta_lanyok_egy_del_ erdelyi_roma_kozosseg_noi_normai/

Blackwell, Debra L., and Daniel T. Lichter. 2004. "Homogamy among Dating, Cohabiting, and Married Couples.” The Sociological Quarterly 45 (4): 719-37.

Blau, Peter Michael, and Joseph E. Schwartz. 1984. Crosscutting Social Circles: Testing a Macrostructural Theory of Intergroup Relations. Transaction Publishers.

Boda, Zsófia, and Bálint Néray. 2015. "Inter-Ethnic Friendship and Negative Ties in Secondary School.” Social Networks 43: 57-72.

Clark-Ibáñez, Marisol, and Diane Felmlee. 2004. „Interethnic Relationships: The Role of Social Network Diversity”. Journal of Marriage and Family 66 (2): 293-305. doi:10.1111/j.1741-3737.2004.00021.x.

Connolly, Jennifer, Wendy Craig, Adele Goldberg, and Debra Pepler. 2004. „MixedGender Groups, Dating, and Romantic Relationships in Early Adolescence”. Journal of Research on Adolescence 14 (2): 185-207. doi:10.1111/j.15327795.2004.01402003.x.

Connolly, Jennifer, Wyndol Furman, and Roman Konarski. 2000. „The role of peers in the emergence of heterosexual romantic relationships in adolescence". Child Development 71 (5): 1395-1408.

Csepeli, György, Zoltán Fábián, and Endre Sík. 1998. „Xenofóbia és a cigányságról alkotott vélemények". In Társadalmi Riport, 458-89. Budapest: TÁRKI.

Csepeli, György, Antal Örkény, and Mária Székelyi. 2000. Grappling with National Identity: How Nations See Each Other in Central Europe. Akadémiai Kiadó.

Duijn, Marijtje AJ, Tom AB Snijders, and Bonne JH Zijlstra. 2004. „p2: a random effects model with covariates for directed graphs". Statistica Neerlandica 58 (2): 234-54.

Eastwick, Paul W., Jennifer A. Richeson, Deborah Son, and Eli J. Finkel. 2009. "Is Love Colorblind? Political Orientation and Interracial Romantic Desire.” 
Personality and Social Psychology Bulletin 35 (9): 1258-68.

doi:10.1177/0146167209338524.

Fisman, Raymond, Sheena S. Iyengar, Emir Kamenica, and Itamar Simonson. 2008. „Racial Preferences in Dating”. The Review of Economic Studies 75 (1): 11732. doi:10.1111/j.1467-937X.2007.00465.x.

FRA - European Union Agency For Fundamental Rights. 2012. The Situation of Roma in 11 EU Member States - Survey Results at a Glance. http://fra.europa.eu/en/publication/2012/situation-roma-11-eu-member-statessurvey-results-glance.

Frankenberg, Ruth. 1993. White Women, Race Matters. Minneapolis: University of Minnesota Press.

Fu, Vincent Kang. 2001. „Racial Intermarriage Pairings”. Demography 38 (2): 147-59.

Gerard, Harold B., Terrence D. Jackson, and Edward S. Conolley. 1975. "Social Contact in the Desegregated Classroom." In School Desegregation, 211-41. Springer.

Giordano, Peggy C., Kenyatta D. Phelps, Wendy D. Manning, and Monica A. Longmore. 2008. „Adolescent academic achievement and romantic relationships”. Social Science Research 37 (1): 37-54. doi:10.1016/j.ssresearch.2007.06.004.

Hajdu, Tamás, Gábor Kertesi, and Gábor Kézdi. 2015. "High-Achieving Minority Students Can Have More Friends and Fewer Adversaries." http://real.mtak.hu/30384/1/bwp1507.pdf.

Havas, Gábor. 2008. „Equality of Opportunity, Desegregation”. In Green Book for the Renewal of Public Education in Hungary, 131-49.

Hitsch, Günter J., Ali Hortaçsu, and Dan Ariely. 2010. „Matching and Sorting in Online Dating”. The American Economic Review 100 (1): 130-63. doi:10.1257/aer.100.1.130.

Joyner, Kara, and Grace Kao. 2005. "Interracial Relationships and the Transition to Adulthood." American Sociological Review 70 (4): 563-81.

Kaba, Amadu Jacky. 2011. "Inter-Ethnic/Interracial Romantic Relationships in the United States: Factors Responsible for the Low Rates of Marriages Between Blacks and Whites." Sociology Mind 1 (3): 121-29.Kalmijn, Matthijs. 1998. „Intermarriage and Homogamy : Causes, Patterns, Trends”. Annual Review of Sociology 24: 395-421. 
Kalmijn, Matthijs. 1993. „Trends in Black/White Intermarriage”. Social Forces 72 (1): 119-46.

Keels, Micere, and Keshia Harris. 2014. „Intercultural Dating at Predominantly White Universities in the United States: The Maintenance and Crossing of Group Borders". Societies 4 (3): 363-79.

Kemény, István, and Janky Béla. 2006. „Roma Population of Hungary 1971-2003.” In Roma of Hungary East European Monographs, 70-225. New York, NJ: COAtlantic Research and Publications.

Kertesi, Gábor, and Gábor Kézdi. 2010. "Iskolázatlan szüllHok Gyermekei és Roma Fiatalok a Középiskolában: Seszámoló Az Educatio Életpálya-Felvételének 2006 és 2009 Közötti Hullámaiból.” Budapest Working Papers on the Labour Market. http://www.econstor.eu/handle/10419/108460.

Kertesi, Gábor, and Gábor Kézdi. 2011. „The Roma/Non-Roma Test Score Gap in Hungary". The American Economic Review 101 (3): 519-25. doi:10.1257/aer.101.3.519.

Kertesi, Gábor, and Gábor Kezdi. 2013. School segregation, school choice and educational policies in 100 Hungarian towns. Budapest: Institute of Economics, Centre for Economic and Regional Studies, Hungarian Academy of Sciences. http://ideas.repec.org/p/has/bworkp/1312.html.

Kertesi, Gábor, and Gábor Kézdi. 2014. „, On the test score gap between Roma and nonRoma students in Hungary and its potential causes”. Budapest Working Papers on the Labour Market.

http://www.econ.core.hu/file/download/bwp/bwp1401.pdf.

Klein, Zev, and Yohanan Eshel. 1980. Integrating Jerusalem Schools. Academic Press. Kreager, Derek A. 2008. “Guarded Borders: Adolescent Interracial Romance and Peer Trouble at School." Social Forces 87 (2): 887-910.

Kreager, Derek A., and Dana L. Haynie. 2011. „Dangerous Liaisons? Dating and Drinking Diffusion in Adolescent Peer Networks". American Sociological Review 76 (5): 737-63. doi:10.1177/0003122411416934.

Kreager, Derek A., and Jeremy Staff. 2009. „The Sexual Double Standard and Adolescent Peer Acceptance”. Social Psychology Quarterly 72 (2): 143-64. doi:10.1177/019027250907200205.

Kovai , Cecília. 2015. A cigány-magyar különbségtétel és a rokonság. Ph.D dissertation, University of Pécs, Faculty of Arts. 
Ladányi, János, and Iván Szelényi. 2006. "Patterns of Exclusion: Constructing Gypsy Ethnicity and the Making of an Underclass”. In Transitional Societies of Europe 676. New York: Columbia University Press.

Lichter, Daniel T., Diane K. McLaughlin, George Kephart, and David J. Landry. 1992. „Race and the Retreat from Marriage: A Shortage of Marriageable Men?”. American Sociological Review 57 (6): 781-99. doi:10.2307/2096123.

Ligeti, György. 2003. Gyújtós: Iskola, Demokrácia, Civilizáció. Budapest: Új Mandátum.

Lubbers, Miranda J. 2003. „Group Composition and Network Structure in School Classes: A Multilevel Application of the p* Model”. Social Networks 25 (4): 309-32.

McCarthy, Bill, and Teresa Casey. 2008. „Love, sex, and crime: Adolescent romantic relationships and offending”. American Sociological Review 73 (6): 944-69.

McClintock, Elizabeth Aura. 2010. „When Does Race Matter? Race, Sex, and Dating at an Elite University". Journal of Marriage and Family 72 (1): 45-72. doi:10.1111/j.1741-3737.2009.00683.x.

McPherson, Miller, Lynn Smith-Lovin, \& James M. Cook. 2001. „Birds of a feather: Homophily in social networks". Annual review of sociology, 415-44.

Miller, Suzanne C., Michael A. Olson, and Russell H. Fazio. 2004. "Perceived Reactions to Interracial Romantic Relationships: When Race Is Used as a Cue to Status." Group Processes \& Intergroup Relations 7 (4): 354-69.

Mok, Teresa A. 1999. „Asian American dating: Important factors in partner choice.” Cultural Diversity and Ethnic Minority Psychology 5 (2): 103.

Moody, James. 2001. „Race, School Integration, and Friendship Segregation in America". American Journal of Sociology 107 (3): 679-716. doi: $10.1086 / 338954$.

Murányi, István. 2006. Identitás és elöitélet. Budapest: Új Mandátum.

Patchen, Martin. 1982. Black-White Contact in Schools: Its Social and Academic Effects. Purdue University Press.

Pettigrew, Thomas F., and Linda R. Tropp. 2006. „A meta-analytic test of intergroup contact theory." Journal of Personality and Social Psychology 90 (5): 751.

Powers, Daniel A., and Christopher G. Ellison. 1995. „Interracial Contact and Black Racial Attitudes: The Contact Hypothesis and Selectivity Bias”. Social Forces 74 (1): 205-26. doi:10.2307/2580629. 
Scheepers, Peer, Mérove Gijsberts, and Marcel Coenders. 2002. „Ethnic exclusionism in European countries. Public opposition to civil rights for legal migrants as a response to perceived ethnic threat". European Sociological Review 18 (1): 1734.

Schoen, Robert, and John Wooldredge. 1989. „Marriage choices in North Carolina and Virginia, 1969-71 and 1979-81 ". Journal of Marriage and the Family, 465-81.

Schofield, Janet W., and Rebecca Eurich-Fulcer. 2001. "When and How School Desegregation Improves Intergroup Relations.” Blackwell Handbook of Social Psychology: Intergroup Processes, 475.

Semyonov, Moshe, Rebeca Raijman, and Anastasia Gorodzeisky. 2006. „The rise of anti-foreigner sentiment in European societies, 1988-2000”. American Sociological Review 71 (3): 426-49.

Simon, Valerie A., Julie Wargo Aikins, and Mitchell J. Prinstein. 2008. „Romantic partner selection and socialization during early adolescence". Child Development 79 (6): 1676-92.

Song, Miri. 2009. “Is Intermarriage a Good Indicator of Integration?” Journal of Ethnic and Migration Studies 35 (2): 331-48.

Snijders, Tom AB. 2011. „Statistical models for social networks”. Annual Review of Sociology 37: 131-53.

Sprecher, Susan, Quintin Sullivan, and Elaine Hatfield. 1994. „Mate selection preferences: Gender differences examined in a national sample". Journal of Personality and Social Psychology 66 (6): 1074-80. doi:10.1037/00223514.66.6.1074.

Strully, Kate. 2013. „Schools as Network Foci: Intsititional and Racial-ethnic Homophily in Adolescent Romantic Relationships." presentation at Sunbelt XXXIII Conference, Hamburg, Germany.

Szabó, Ildikó, and Antal Örkény. 1998. Tizenévesek állampolgári Kultúrája. Minoritás Alapítvány.

Tóth, Á, and J. Vékás. 2008. „Család és identitás. A vegyes házasság szerepe a magyarországi kisebbségi közösségek reprodukciójában”. Demográfia 51 (4): $329-55$.

Vaquera, Elizabeth, and Grace Kao. 2005. "Private and Public Displays of Affection Among Interracial and Intraracial Adolescent Couples.” Social Science Quarterly 86: 485-508. 
Váradi, Luca. 2014. Youths Trapped in Prejudice: Hungarian Adolescents' Attitudes Towards the Roma. Springer Science \& Business.

Vermeij, Lotte, Marijtje A. J. van Duijn, and Chris Baerveldt. 2009. „Ethnic segregation in context: Social discrimination among native Dutch pupils and their ethnic minority classmates". Social Networks 31 (4): 230-39. doi:10.1016/j.socnet.2009.06.002.

Wimmer, Andreas, and Kevin Lewis. 2010. „Beyond and Below Racial Homophily: ERG Models of a Friendship Network Documented on Facebook”. American Journal of Sociology 116 (2): 583-642.

Yancey, George. 2007. „Homogamy over the net: Using internet advertisements to discover who interracially dates”. Journal of Social and Personal Relationships 24 (6): 913-30.

Zijlstra, Bonne JH, Marijtje AJ van Duijn, and Tom AB Snijders. 2006. „The Multilevel p2 Model". Methodology 2 (1): 42-47.

Zijlstra, Bonne JH, René Veenstra, and Marijtje AJ Van Duijn. 2008. „A multilevel p2 model with covariates for the analysis of binary bully-victim network data in multiple classrooms". In Modeling dyadic and interdependent data in the developmental and behavioral sciences, 369-86. 
Table 1. Ethnicity, parental background and academic tracking by schools in the sample

\begin{tabular}{|c|c|c|c|c|}
\hline School / tracking & Location & $\mathrm{N}^{*}$ & Roma & $\begin{array}{l}\text { Low parental } \\
\text { education }\end{array}$ \\
\hline \multicolumn{5}{|l|}{ School 1} \\
\hline Grammar school & Budapest & 124 & $0.9 \%$ & $12.3 \%$ \\
\hline \multicolumn{5}{|l|}{ School 2} \\
\hline Vocational grammar school & Budapest & 111 & $18.6 \%$ & $57.7 \%$ \\
\hline Vocational school & Budapest & 96 & $34.9 \%$ & $76.5 \%$ \\
\hline \multicolumn{5}{|l|}{ School 3} \\
\hline Grammar school & City I & 155 & $0.0 \%$ & $9.4 \%$ \\
\hline \multicolumn{5}{|l|}{ School 4} \\
\hline Vocational grammar school & City I & 99 & $46.2 \%$ & $72.8 \%$ \\
\hline Vocational school & City I & 151 & $62.7 \%$ & $86.2 \%$ \\
\hline \multicolumn{5}{|l|}{ School 5} \\
\hline Grammar school & Town I & 86 & $4.8 \%$ & $37.8 \%$ \\
\hline \multicolumn{5}{|l|}{ School 6} \\
\hline Vocational grammar school & Town I & 101 & $19.6 \%$ & $76.9 \%$ \\
\hline Vocational school & Town I & 78 & $53.4 \%$ & $91.9 \%$ \\
\hline \multicolumn{5}{|l|}{ School 7} \\
\hline Grammar school & Town II & 97 & $9.7 \%$ & $32.6 \%$ \\
\hline Vocational grammar school & Town II & 32 & $20.7 \%$ & $44.0 \%$ \\
\hline Vocational school & Town II & 83 & $63.6 \%$ & $87.3 \%$ \\
\hline Total sample & & 1113 & $27.4 \%$ & $53.8 \%$ \\
\hline
\end{tabular}

Notes: *N: Students, where the ethnicity is non-missing **Low parental education:

mother's education is vocational school or lower

Table 2. Attraction and preference for dating by ethnicity

\begin{tabular}{lrr}
\hline \multirow{3}{*}{ Sender } & \multicolumn{2}{c}{ Receiver } \\
\hline \multicolumn{3}{c}{ Nonds attractive } \\
Non-Roma & $15.4 \%$ & Roma \\
Roma & $7.3 \%$ & $15.4 \%$ \\
& & \\
Non-Roma & Would date & \\
Roma & $3.5 \%$ & $2.1 \%$ \\
& $2.6 \%$ & $4.1 \%$
\end{tabular}


Table 3. Multilevel p2 estimates of the effects of ethnicity, class composition, personal contact and isolated status on attraction.

\begin{tabular}{|c|c|c|c|}
\hline Effect & Column A & Column B & Column C \\
\hline Density & $-1.99(0.63)^{* *}$ & $-2.36(0.74)^{* *}$ & $-2.18(0.74)^{* *}$ \\
\hline Reciprocity & $0.22(0.48)$ & $0.26(0.46)$ & $-0.16(0.35)$ \\
\hline
\end{tabular}

\section{Receiver covariates}

$\begin{array}{llll}\text { Receiver Roma } & -1.72(0.43)^{* *} & 0.88(0.70) & 0.76(0.74)\end{array}$

\section{Dyadic covariates}

Share of Roma

Share $\mathrm{x}$ receiver Roma

Has any friends

Has Roma friends

Has any friends $\mathrm{x}$ receiver Roma

Has Roma friends x receiver Roma

Friend

Friend $\mathrm{x}$ receiver Roma

\section{Random effects}

Class density variance

Sender variance

Receiver variance

Sender receiver covariance

$\begin{array}{lll}-4.56(1.02)^{* * *} & -4.94(0.92)^{* *} & -4.97(0.78)^{* *} \\ 2.33(1.07)^{*} & 1.45(1.01) & 1.71(1.09) \\ & 0.88(0.42)^{*} & 0.67(0.41) \\ & -0.17(0.22) & -0.20(0.24) \\ & -3.15(0.60)^{* *} & -2.78(0.63)^{* *} \\ & 1.20(0.37)^{* *} & 0.84(0.36)^{*} \\ & & 1.83(0.14)^{* *} \\ & & -0.29(0.43)\end{array}$

$2.27(1.00)$

$2.97(1.27)$

3.27 (1.67)

$3.98(0.34)$

$4.05(0.35)$

$4.01(0.33)$

$3.35(0.30)$

$3.45(0.31)$

$3.13(0.27)$

$0.13(0.22)$

$0.10(0.26)$

$-0.01(0.21)$

$\begin{array}{llll}\text { Number of dyads } & 9,340 & 9,329 & 8,908\end{array}$

Notes: Posterior mean (Posterior S.D.), **: $\mathrm{p}<0.01,{ }^{*}: \mathrm{p}<0.05$ 
Table 4. Multilevel p2 estimates of the effects of ethnicity, class composition, personal contact and isolated status on willingness to date.

\begin{tabular}{|c|c|c|c|}
\hline Effect & Column A & Column B & Column C \\
\hline Density & $-5.19(0.43) * *$ & $-5.77(0.75)^{* *}$ & $-5.42(0.57) * *$ \\
\hline Reciprocity & $0.61(1.65)$ & $0.69(1.40)$ & $0.31(1.56)$ \\
\hline \multicolumn{4}{|l|}{ Receiver covariates } \\
\hline Receiver Roma & $-1.07(0.60)$ & $0.60(1.14)$ & $0.54(1.10)$ \\
\hline \multicolumn{4}{|l|}{ Dyadic covariates } \\
\hline Share of Roma & $-3.33(1.36)^{* *}$ & $-3.85(1.77)^{* *}$ & $-3.70(1.28) * *$ \\
\hline Share x receiver Roma & $2.11(1.64)$ & $1.54(1.74)$ & $1.67(1.64)$ \\
\hline Has any friends & & $0.44(0.67)$ & $-0.09(0.61)$ \\
\hline Has Roma friends & & $0.02(0.37)$ & $-0.11(0.34)$ \\
\hline Has any friends $\mathrm{x}$ receiver Roma & & $-2.82(1.17)^{*}$ & $-2.34(1.12)$ \\
\hline Has Roma friends x receiver Roma & & $1.83(0.79)^{*}$ & $1.31(0.75)$ \\
\hline Friend & & & $2.28(0.20)^{* *}$ \\
\hline Friend $\mathrm{x}$ receiver Roma & & & $-0.21(0.65)$ \\
\hline \multicolumn{4}{|l|}{ Random effects } \\
\hline Class density variance & $0.86(0.35)$ & $1.15(0.82)$ & $0.98(0.51)$ \\
\hline Sender variance & $5.38(0.91)$ & $6.06(0.84)$ & $5.48(0.74)$ \\
\hline Receiver variance & $1.79(0.33)$ & $2.08(0.38)$ & $1.62(0.26)$ \\
\hline Sender receiver covariance & $-0.67(0.34)$ & $-0.63(0.42)$ & $-0.71(0.39)$ \\
\hline Number of dyads & $9,9,340$ & 9,329 & 8,908 \\
\hline
\end{tabular}

Notes: Posterior mean (Posterior S.D.), **: $\mathrm{p}<0.01,{ }^{*}: \mathrm{p}<0.05$ 
Table 5. Alternative specifications of the multilevel p2 models.

\begin{tabular}{|c|c|c|c|c|c|}
\hline Effect & Column A & Column B & Column C & Column D & Column E \\
\hline Dependent variable & would date & finds attractive & would date & finds attractive & would date \\
\hline Density & $-6.45(0.64)^{* *}$ & $-0.79(0.83)$ & $-5.22(0.44)^{* *}$ & $-1.68(0.73)^{*}$ & $-5.17(0.46)^{* *}$ \\
\hline Reciprocity & $-0.03(1.35)$ & $0.05(0.52)$ & $0.72(1.86)$ & $0.13(0.45)$ & $0.39(2.08)$ \\
\hline \multicolumn{6}{|l|}{ Receiver covariates } \\
\hline Receiver Roma & $-0.56(1.05)$ & $-1.27(0.55)^{*}$ & $-0.69(0.80)$ & $0.02(0.62)$ & $0.08(1.04)$ \\
\hline \multicolumn{6}{|l|}{ Dyadic covariates } \\
\hline Share of Roma & $-1.09(1.05)$ & $-4.40(0.83)^{* *}$ & $-3.68(1.40)^{* *}$ & $-4.55(0.80)^{* *}$ & $-3.81(1.18)^{* *}$ \\
\hline Share $\mathrm{x}$ receiver Roma & $-0.22(1.66)$ & $1.69(1.15)$ & $1.63(1.91)$ & $0.90(1.11)$ & $0.75(1.86)$ \\
\hline Has any friends & $-0.41(0.55)$ & & & & \\
\hline Has Roma friends & $-0.42(0.35)$ & & & & \\
\hline Has any friends $\mathrm{x}$ receiver Roma & $-0.27(1.14)$ & & & & \\
\hline Has Roma friends $\mathrm{x}$ receiver Roma & $1.32(0.76)$ & & & & \\
\hline $\mathrm{N}$ of friends & & $0.02(0.02)$ & $-0.03(0.03)$ & & \\
\hline $\mathrm{N}$ of Roma friends & & $-0.19(0.10)^{*}$ & $-0.04(0.18)$ & & \\
\hline $\mathrm{N}$ of friends $\mathrm{x}$ receiver Roma & & $-0.07(0.05)$ & $-0.07(0.09)$ & & \\
\hline $\mathrm{N}$ of Roma friends $\mathrm{x}$ receiver Roma & & $0.28(0.13)^{*}$ & $0.29(0.22)$ & & \\
\hline $\log \mathrm{N}$ of friends ${ }^{1}$ & & & & $0.30(0.14)^{*}$ & $-0.11(0.21)$ \\
\hline $\log \mathrm{N}$ of Roma friends ${ }^{1}$ & & & & $-0.41(0.23)$ & $0.02(0.35)$ \\
\hline $\log N$ of friends $x$ receiver Roma ${ }^{1}$ & & & & $-1.09(0.29)^{* *}$ & $-0.82(0.54)$ \\
\hline $\log N$ of Roma friends $x$ rec. Roma $^{1}$ & & & & $1.20(0.35)^{* *}$ & $1.20(0.68)$ \\
\hline Friend & $1.29(0.25)^{* *}$ & $1.79(0.15)^{* *}$ & $2.27(0.22)$ & $1.77(0.15)^{* *}$ & $2.25(0.21)^{* *}$ \\
\hline Friend $\mathrm{x}$ receiver Roma & $-0.17(0.71)$ & $-0.36(0.41)$ & $-0.38(0.67)$ & $-0.29(0.45)$ & $-0.23(0.70)$ \\
\hline Finds alter attractive & $4.59(0.24)^{* *}$ & & & & \\
\hline \multicolumn{6}{|l|}{ Random effects } \\
\hline Class density variance & $0.60(0.32)$ & $6.49(3.84)$ & $0.94(0.46)$ & $4.28(2.31)$ & $0.91(0.41)$ \\
\hline Sender variance & $4.17(0.95)$ & $3.91(0.35)$ & $4.93(0.63)$ & $4.00(0.35)$ & $5.26(0.61)$ \\
\hline Receiver variance & $0.13(0.06)$ & $2.90(0.32)$ & $1.57(0.31)$ & $3.07(0.28)$ & $1.22(0.35)$ \\
\hline Sender receiver covariance & $-0.17(0.27)$ & $-0.03(0.21)$ & $-0.88(0.35)$ & $-0.02(0.20)$ & $-0.80(0.44)$ \\
\hline Number of dyads & 8,908 & 8,908 & 8,908 & 8,908 & 8,908 \\
\hline
\end{tabular}

Notes: Posterior mean (Posterior S.D.), **: ${ }^{*}<0.01,{ }^{*}: \mathrm{p}<0.05$

1. $\log \mathrm{N}$ of friends and $\log \mathrm{N}$ of Roma friends are calculated as $\ln (\mathrm{N}$ of friends +1$)$ and

$\ln (\mathrm{N}$ of Roma friends +1$)$ 
Figure 1. Distribution of the share of Roma students in the sample classes. 